Discussion Paper No. 11-012

\title{
International Diversification with Securitized Real Estate and the Veiling Glare from Currency Risk
}

Tim-Alexander Kroencke and Felix Schindler

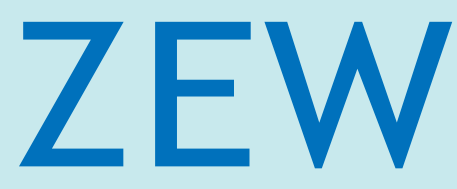

Zentrum für Europäische Wirtschaftsforschung $\mathrm{GmbH}$

Centre for European

Economic Research 
Discussion Paper No. 11-012

\section{International Diversification with Securitized Real Estate and the Veiling Glare from Currency Risk}

Tim-Alexander Kroencke and Felix Schindler

Download this ZEW Discussion Paper from our ftp server:

ftp://ftp.zew.de/pub/zew-docs/dp/dp11012.pdf

Die Discussion Papers dienen einer möglichst schnellen Verbreitung von neueren Forschungsarbeiten des ZEW. Die Beiträge liegen in alleiniger Verantwortung der Autoren und stellen nicht notwendigerweise die Meinung des ZEW dar.

Discussion Papers are intended to make results of ZEW research promptly available to other economists in order to encourage discussion and suggestions for revisions. The authors are solely responsible for the contents which do not necessarily represent the opinion of the ZEW. 


\section{Non-technical Summary}

Do investments in international securitized real estate markets make a statistically significant contribution to an internationally diversified mixed-asset portfolio, and does currency risk exposure have an impact on the results? These questions have become more and more popular for both private and institutional investors as well as researchers in the last years and are therefore guideline and motivation for our analysis.

For the empirical analysis, we use monthly data on bond, stock, and real estate market index returns from nine countries around the world for the period from 1986 to 2009, which can be considered representative. To our knowledge, this is the first study applying spanning tests for such a broad range of markets and assets while simultaneously considering currency risk exposure, which we see as an important contribution of our paper to the existing literature. Applying regression-based and stochastic discount factor-based spanning tests suggested by Huberman and Kandel (1987) and De Roon et al. (2001) allows us to measure diversification benefits by their statistical significance and to statistically check whether a shift of the meanvariance frontier is too large to be attributed to chance.

Our main findings are as follows. First, for a US investor invested in a diversified US mixedasset portfolio, international bonds and stocks provide only slightly significant diversification benefits when currency risk is not hedged. Second, adding international securitized real estate to an internationally diversified bond and stock portfolio provides significant diversification benefits. Third, taking into account currency risk further strengthens the results. In this setting, even the shift of the tangency portfolio becomes highly significant for international bonds, but again, this does not apply to international stocks. In the case of real estate, all conducted tests strongly reject the hypothesis of spanning for the efficient frontier and of intersection for both the minimum variance portfolio and the tangency portfolio - even if the benchmark of US real estate, international bonds, and international stocks is challenging and quite restrictive. The results from out-of-sample analysis and a setting with short selling constraints mainly confirm the findings.

Summarizing, it is shown that neglecting international real estate in an international mixedasset portfolio results in a loss of investors' diversification opportunities and that a fully currency-hedged strategy yields significant diversification benefits relative to unhedged currency risk exposure. 


\section{Das Wichtigste in Kürze}

Leisten die verbrieften internationalen Immobilienmärkte in einem Mixed-Asset-Kontext einen statistisch signifikanten Beitrag zur internationalen Portfoliodiversifikation und welchen Einfluss hat das Währungsrisiko auf die Ergebnisse? Diese Fragestellungen haben in den letzten Jahren sowohl bei privaten und institutionellen Investoren als auch in der Wissenschaft zunehmend an Bedeutung gewonnen und bilden daher die Motivation für die vorliegende Studie.

Die empirische Analyse basiert auf monatlichen Renditedaten für Anleihe-, Aktien- und Immobilienmärkte in insgesamt neun Ländern über einen Zeitraum von 1986 bis 2009. Statistisch beruht die Analyse auf den Testverfahren von Huberman und Kandel (1987) sowie von De Roon et al. (2001), mittels derer überprüft werden kann, ob durch die Aufnahme zusätzlicher Vermögensgüter in ein Portfolio sowohl die gesamte Effizienzgrenze als auch das Minimum-Varianz-Portfolio bzw. das Tangentialportfolios statistisch signifikant verschoben werden.

Die zentralen Ergebnisse sind wie folgt: Erstens, aus der Sicht eines US-Investors, der bereits ein national ausgerichtetes Mixed-Asset-Portfolio hält, bieten internationale Aktien und Anleihen ohne Währungsabsicherung nur ein begrenztes Diversifikationspotential. Zweitens, die Beimischung von internationalen Immobilienanlagen in ein bereits international ausgerichtetes Anleihen- und Aktienportfolio resultiert dagegen in signifikanten Vorteilen. Drittens, auf Basis von währungsbesicherten Anlagen werden diese Ergebnisse bestärkt. Gerade für internationale Immobilienanlagen ergeben sich sogar als Beimischung zu einem bereits in internationale Anleihen und Aktien sowie US-amerikanische Immobilien investierten Portfolio statistisch hoch signifikante Diversifikationsgewinne. Diese Ergebnisse erweisen sich in einer Out-of-Sample-Analyse sowie unter Ausschluss von Leerverkäufen als weitgehend robust.

Zusammenfassend ist festzuhalten, dass die Vernachlässigung von internationalen Immobilienanlagen in einem internationalen Mixed-Asset-Portfolio zu signifikanten Einbußen der Diversifikationsmöglichkeiten führt und dass Währungsabsicherungen ebenfalls einen statistisch signifikanten Beitrag zur Diversifikation leisten. 


\title{
International Diversification with Securitized Real Estate and the Veiling Glare from Currency Risk
}

\author{
Tim-Alexander Kroencke $^{*}$ and Felix Schindler ${ }^{\dagger}$
}

February 2011

\begin{abstract}
This paper analyzes diversification benefits from international securitized real estate in a mixed-asset context. We apply regression-based mean-variance efficiency tests, conditional on currency-unhedged and fully hedged portfolios to account for foreign exchange risk exposure. From the perspective of a US investor, it is shown that first, international diversification is superior to a US mixed-asset portfolio, second, adding international real estate to an already internationally diversified stock and bond portfolio results in a further significant improvement of the risk-return trade-off and, third, considering unhedged international assets could lead to biased asset allocation decisions not realizing the true diversification benefits from international assets. Our in-sample results are quite robust in out-of-sample analysis and when investment frictions like short selling constraints are introduced.
\end{abstract}

Keywords: Diversification Benefits; International Mixed-Asset Portfolios; Currency Hedging; Spanning Tests; Short Selling Constraints

JEL Classifications: G11; G12; G15

* $\quad$ Corresponding author: Researcher at the Centre for European Economic Research (ZEW), P.O. Box 1034 43, D-68034 Mannheim, Germany; Phone: +49-621-1235-370; Fax: +49-621-1235-223; E-mail: kroencke@zew.de.

$\dagger \quad$ Researcher at the Centre for European Economic Research (ZEW) and Assistant Professor of Real Estate at the Steinbeis University Berlin (SHB), P.O. Box 1034 43, D-68034 Mannheim, Germany; Phone: +49-6211235-378; Fax: +49-621-1235-223; E-mail: schindler@zew.de. 


\section{Introduction}

Do investments in international securitized real estate markets make a statistically significant contribution to an internationally diversified mixed-asset portfolio, and does currency risk exposure have an impact on the results? These questions are becoming more and more popular for both private and institutional investors for several reasons. First, (securitized) real estate has been a fast-growing asset class around the world during the last decades. In many countries, REIT legislation has been introduced, improving the institutional framework and legal setting of real estate companies, both the number of listed real estate companies and their market capitalization have increased tremendously, coverage by analysts and investors has augmented, and therefore, securitized real estate now cumulatively offers a suitable opportunity to overcome the drawbacks from investments in direct real estate. Second, analyses of portfolio allocation show that there is a significant home-bias in many portfolios, which results in limited diversification benefits and raises the questions for additional benefits from internationally well diversified portfolios. Third, many studies show that cross-country diversification benefits for pure stock portfolios have been decreasing over time due to increasing financial integration of global stock markets. Thus, investors are looking for other assets, such as real estate, to provide diversification benefits. Fourth, most studies analyzing diversification benefits by statistically testing the shift in the efficient frontier based on spanning tests focus either on stock markets of developed (Kan and Zhou, 2008; Glabadanidis, 2009; Eun et al., 2010) or developing countries (Schroeder, 2000; De Roon et al., 2001; Driessen and Laeven, 2007) but do not consider real estate in particular. Therefore, given the mentioned facts and the increased relevance of real estate investments in the recent past, the two central questions above are the guideline and motivation for our analysis.

Compared to previous studies applying spanning tests such as De Roon et al. (2001), Driessen and Laeven (2007), and Kan and Zhou (2008), in our analysis, we extend the investment universe from international bond and stock markets to international securitized real estate markets and further consider the impact of currency risk exposure. For the empirical analysis, we use monthly data on bond, stock, and real estate market index returns from nine countries for the period from 1986 to 2009. The considered markets are located in Asia, Australia, Europe, and North America, cover a large portion of market capitalization in global stock and real estate markets and can therefore be considered representative. 
The statistical significance of the diversification benefits is analyzed by regression-based spanning tests for the complete efficient frontier and intersection tests for the global minimum variance portfolio and the tangency portfolio as suggested by Huberman and Kandel (1987), and De Roon et al. (2001). The mean-variance frontier can by definition only shift outwards when a set of assets is added to the investment universe. However, mean-variance spanning tests can be used to check whether a shift of the mean-variance frontier is too large to be attributed to chance. Performing statistical tests allows us to measure and compare diversification benefits from international stocks, bonds, and real estate by their statistical significance.

Taking the perspective of a US investor, we start with a mixed-asset portfolio based on US bonds, stocks, and real estate. In three steps, we successively add international bonds, international stocks, and international real estate to this portfolio. We test the contribution of the different assets by two settings - first by using unhedged returns and second by using fully currency-hedged returns to control for the additional risk of the currency exposure. ${ }^{1}$ Almost every time an investor invests abroad, the asset allocation will be exposed to exchange rate risk. Thus, if investors consider international assets on an unhedged basis to derive an asset allocation decision, the core asset price risk and the exchange rate risk being taken to be inseparable, they could "fail to realize the full diversification benefits of international investing” (Dales and Meese, 2001, p. 10). There is no apparent reason why such unintentional exposures in a foreign currency should be in line with an optimal portfolio allocation. Moreover, there is no reason to even measure diversification benefits from foreign assets jointly with the corresponding exchange rate components. Furthermore, separating asset price risk from exchange rate risk is quite simple since exchange rate markets are highly liquid, and thus, it is relatively easy to unwind an unintended exposure in the forward market.

To our knowledge, this is the first study applying mean-variance efficiency tests to such a broad range of markets and assets, while simultaneously considering currency risk exposure which we see as an important contribution of our paper to the existing literature.

The findings from our analysis related to international bond and stock markets show that mean-variance efficiency is only weakly rejected for currency-unhedged returns while the intersection hypothesis for the tangency portfolio is not rejected at all, which is in line with

1 Glen and Jorion (1993), Jorion (1994), De Roon et al. (2003), and most recently Campbell et al. (2010a) show that currency risk has substantial impact on the mean-variance frontier when international allocations are computed from bonds and stocks. 
the results from Kan and Zhou (2008), among others. However, the results are stronger for international real estate, indicating that the efficient frontier is shifted upwards significantly when international real estate is added to an existing portfolio consisting of international bonds and stocks, while the tangency portfolio is still not significant. This result is less ambiguous when currency risk exposure is fully hedged. In this setting, even the shift of the tangency portfolio is significant and there is a substantial increase in the Sharpe ratio. The results from out-of-sample analysis and a setting with short selling constraints confirm the findings. Therefore, the contribution of international real estate to an internationally diversified bond and stock portfolio is meaningful and investors are well advised to add real estate to their portfolio allocation.

The organization of this paper is as follows. Section 2 provides a brief literature review. Section 3 discusses the methodology before Section 4 shows how currency risk of foreign assets can be hedged and separated from core asset price risk. Section 5 describes the data characteristics. In Section 6, we report our empirical results and discuss the implications of our findings. In Section 7, we apply out-of-sample tests and introduce market and investment frictions in form of short selling constraints as a robustness check, and study the time trends of diversification benefits. Section 8 offers a summary and provides concluding remarks.

\section{Literature Review}

Portfolio diversification can mainly be improved in two dimensions. Investors can seek for additional asset classes, with the rationale that returns across them are not perfectly correlated. Furthermore, international diversification is intended to reduce the risk of a portfolio, in the hope that returns across countries are not perfectly correlated (e.g. Grubel, 1968 and Solnik, 1974). Unfortunately, as international capital markets have become more integrated over the last decades, international asset markets are considered to be increasingly correlated with each other. Indeed, such a tendency is well documented for international stock markets (e.g. Eun and Lee, 2010). Driessen and Leaven (2007) apply mean-variance spanning tests for stock markets from developed and developing countries. They document larger diversification benefits for developing countries than for developed countries, and find decreasing diversification benefits over the sample period from 1985 to 2002. Kan and Zhou (2008) apply mean-variance spanning tests to study the benefits of international diversification for a US investor and test the improvement of the tangency portfolio when seven currency riskunhedged international stock markets of developed countries are added to the investment universe of US bonds and stocks. They find a statistically significant improvement for the 
tangency portfolio only for the period from 1970 to 1988. By contrast, the improvement is statistically insignificant for the most recent period from 1989 to 2006, implying only weak diversification benefits from international stocks.

Eichholtz (1996) argues that real estate returns could exhibit lower international correlation than common stocks due to the local nature of real estate markets. In consequence of the circumstance that investing in direct real estate in an international environment is quite difficult, an alternative considered is securitized real estate, i.e., exchange-traded real estate operating companies. For the most part, such companies' main focus lies on owning and letting property. Thus, they reflect the local real estate markets but are still highly liquid and therefore well comparable to bonds and common stocks.

We mention only a handful of studies that cover real estate and are closest to ours, Worzala and Sirmans (2003) give a more comprehensive review of the relevant literature. Chen et al. (2005) apply mean-variance spanning tests in a national setup with US-REITs, and find significant diversification benefits towards US common stocks over the period from 1980 to 2002. Chiang and Lee (2007) follow them, covering the period from 1980 to 2004, but also include US bonds as benchmark assets. They consider both US direct real estate and US securitized real estate as an additional portfolio diversifier, and find a significant improvement of the investment opportunity set for direct real estate in mixed-asset portfolios. However, they are not able to make the same decisive conclusion for securitized real estate. Rubens et al. (1998) measure diversification gains from international investing in Japan, the UK, and the US from 1978 to 1993. They cover US bonds, US stocks, and US direct real estate as benchmark assets. However, only bonds and stocks are considered international assets. The currency risk is unhedged and insignificant diversification benefits are reported for the tangency portfolio. The results of Rubens et al. (1998) are quite representative, since in the literature currency-unhedged international assets are not found to be a statistically significant portfolio diversifier (e.g. Kan and Zhou, 2008; Glabadanidis, 2009; Eun et al., 2010).

Several studies have examined factor models, exploring global or common risk factors driving returns of international securitized real estate. Bond et al. (2003) study currency-unhedged real estate return characteristics from 14 countries over the period from 1990 to 2001, and identify country-specific factors, indicating potential diversification benefits. Liu and Mei (1998) also use a factor model to analyze securitized real estate and common stocks from Australia, France, Japan, South Africa, the UK, and the US for the period from 1980 to 1991. They compare currency-unhedged as well as hedged returns, and compute mean-variance 
efficient portfolios for both cases. Even though their results indicate diversification benefits for international real estate, they do not provide evidence of statistical significance.

Even though there is a wide range of studies focusing on diversification benefits from international mixed-asset portfolios, there is a gap in the literature. The literature does not cover the statistical testing of the significance of diversification benefits from investments in international securitized real estate markets, while simultaneously explicitly considering the impact of investors' exchange rate risk exposure. By applying mean-variance efficiency tests in the context of mixed-asset portfolios based on a broad range of national markets and three different assets, the contribution of this paper is to narrow this gap and to shed further light on this topic against the background of existing research.

\section{Methodology}

\subsection{Regression-Based Tests}

We apply the regression-based intersection and spanning tests proposed by Huberman and Kandel (1987) and Jobson and Korkie (1989) to measure diversification benefits from international real estate and other assets. If the mean-variance frontier constructed from some benchmark assets coincides with the frontier with a set of additional test assets, the benchmark assets span the frontier of all assets, and it is not possible to improve the investment opportunity set with the test assets. However, given a specific sample, the meanvariance frontier of the broader set of assets shifts outwards with respect to the frontier of the smaller set by definition. The following tests measure the statistical significance and indicate whether a shift of the frontier is too large to be attributed to chance. The literature and the following distinguishes between testing "spanning”, i.e. testing a shift of the complete meanvariance frontier, and testing “intersection”, i.e. testing a shift of the mean-variance frontier at a pre-specified single point that is of special interest of the investor.

Consider a vector of $N+K$ asset returns, $1+r_{t}=R_{t}=\left(R_{K t}^{\prime}, R_{N t}^{\prime}\right)$, where $R_{K t}$ are $K$ benchmark asset returns and $R_{N t}$ are $N$ test asset returns at time $t$, which satisfy the asset pricing equation $E\left[m_{t} R_{t}\right]=1_{N+K}$, with a stochastic discount factor $m_{t}$. Spanning and intersection tests can be based on the regression of the $N$ test assets on the $K$ benchmark assets,

$R_{N t}=\alpha+\beta R_{K t}+\varepsilon_{t}$ 
Huberman and Kandel (1987) show, that intersection can be tested by the $N$ restrictions,

$$
H_{0}: \alpha v+\beta 1_{K}-1_{N}=0_{N}
$$

for a given value of $v$. Setting $v$ to the inverse of the risk-free rate, $v=E\left[m_{t}\right]=1 / R_{f}$, is an intersection test of the tangency portfolio. If the coefficient restriction above cannot be rejected, the mean-variance frontier of the benchmark assets and the mean-variance frontier with the additional test assets intersect at the tangency portfolio and it is not possible to improve the portfolio performance at this point of the frontier. Similarly, setting $v$ to zero is an intersection test at the global minimum variance portfolio in the mean-variance space. Spanning can be examined by testing intersection for all possible values of $v$, and is equivalent to the $2 N$ restrictions $\alpha=0_{N}$ and $\beta 1_{K}-1_{N}=0_{N}$ without market frictions.

Intuitively, if the hypothesis of spanning holds, it is possible to find a portfolio of $K$ benchmark assets with the same mean but a lower or at least equal variance as the test assets, since all the elements of $\alpha$ are equal to zero and the elements of $\beta$ add up to one. If the disturbances $\varepsilon_{t}$ are independent and identically distributed, intersection (\#=1) and spanning (\#=2) can be tested with an exact F-test, $F \sim F_{\# N, \#(T-K-N)}$. When the distributions of the $\varepsilon_{t}$ are non-normally distributed, the generalized method of moments (GMM) with a NeweyWest covariance estimator can be used for a heteroscedasticity-robust and autocorrelationrobust asymptotic Wald test, $W_{\text {HAC }} \sim \chi_{\# N}^{2} \cdot{ }^{2}$ Bekaert and Urias (1996) propose a stochastic discount factor (SDF)-based test for mean-variance efficiency, directly exploiting the asset pricing equation via Hansen and Jagannathan (1991) bounds. They also show that the restrictions imposed by the SDF-based test are equivalent to the restrictions imposed by Huberman and Kandel (1987). A detailed discussion of the SDF test follows in Appendix III. The SDF-based tests and the regression-based tests allow us to draw almost identical conclusions. De Roon and Nijman (2001) give a survey on the mean-variance efficiency test statistics. Implementation issues are discussed in detail by Kan and Zhou (2008).

\subsection{Regression-Based Tests with Short Selling Constraints}

In the presence of market frictions in form of short selling constraints, the asset pricing equation becomes an inequality, $E\left[m_{t} R_{t}\right] \leq 1_{N+K}$ (see He and Modest, 1995; Luttmer, 1996).

\footnotetext{
${ }^{2}$ We use the Bartlett kernel with four lags throughout the study, if not otherwise mentioned.
} 
The inequality sign can be attributed to the fact that negative pricing errors are in principle allowed under short selling constraints, since negative pricing errors would imply that an investor should optimally shorten the corresponding asset. This is not possible by assumption. According to this, De Roon et al. (2001) derive from the asset pricing inequality above that intersection can be tested by testing an inequality form of the restrictions imposed by Huberman and Kandel (1987),

$$
\begin{aligned}
& R_{N t}=\alpha^{(v)}+\beta^{(v)} R_{K t}^{(v)}+\varepsilon_{t}^{(v)}, \\
& H_{0}: a_{J}(v)=\alpha^{(v)} v+\beta^{(v)} 1_{K}-1_{N} \leq 0_{N},
\end{aligned}
$$

where $R_{K t}^{(v)}$ are those benchmark assets, for which the short selling constraints are not binding for a given risk-free interest rate. De Roon et al. (2001), and more generally Kodde and Palm (1986), show that the inequality restrictions above can be tested with a Wald-type test statistic,

$$
W_{S}=\underbrace{\min }_{\{\lambda \leq 0\}}\left(\widehat{a_{J}}(v)-\lambda\right)^{\prime}\left(\operatorname{Var}\left(\widehat{a_{J}}(v)\right)\right)^{-1}\left(\widehat{a_{J}}(v)-\lambda\right),
$$

where $\widehat{a_{J}}(v)$ is the sample equivalent of $a_{J}(v)$. The test statistic is asymptotically distributed as a mixture of $\chi^{2}$ distributions. As in De Roon et al. (2001), we use numerical simulations as proposed by Gouriéroux et al. (1982) to find the weights of the distribution. We use OLS as well as GMM estimates for a heteroscedasticity-robust and autocorrelation-robust test, as is the case without short selling constraints.

To give an intuition on the test statistic $W_{S}$, note that the coefficients $a_{J}(v)$ can be interpreted as Jensen alphas, as discussed in De Roon et al. (2001). Hence, the test statistic $W_{s}$ allows negative Jensen's alphas to some degree, and again a negative Jensen’s alpha (or 'pricing error') would imply to optimally shorten the corresponding asset.

Without market frictions, the complete mean-variance frontier can be obtained from two distinct points on it. However, with short selling constraints the mean-variance frontier is a rather segmented frontier of unrestricted mean-variance frontiers of the assets for which the short selling constraints are not binding for a given value of $v$. Accordingly, there is no simple, generalized spanning test, as is the case without market frictions (see De Roon et al. (2001) for details). In the presence of short selling constraints, we will report intersection tests for the global minimum variance portfolio and the tangency portfolio to draw a fair picture of 
the diversification benefits at the certainly most interesting regions of the mean-variance frontier.

\section{Compartmentalizing Currency Risk from Asset Price Risk}

We apply mean-variance efficiency tests conditional on currency-unhedged and fully currency-hedged returns. Thereby we will account for the real hedging costs investors are opposed by using forward exchange rate market data. This section is devoted to showing how we disentangle currency risk exposure from core asset price risk. For $S_{t}$ being the spot US dollar price of one unit of a foreign currency, and $P_{t}^{*}$ the price of the foreign asset inclusive of reinvestments in the local currency the currency-unhedged returns in US dollars are measured as

$r_{t+1}^{\$}=P_{t+1}^{*} S_{t+1} / P_{t}^{*} S_{t}-1$

The unhedged US dollar return can be decomposed in a local currency asset return, $r_{t+1}^{*}=P_{t+1}^{*} / P_{t}^{*}-1$, an exchange rate component, $s_{t+1}=S_{t+1} / S_{t}-1$, and a cross product component $r_{t+1}^{*} s_{t+1}$ resulting in:

$r_{t+1}^{\$}=r_{t+1}^{*}+s_{t+1}+r_{t+1}^{*} S_{t+1}$.

To hedge currency risk of a foreign asset, forward contracts can be used. Let $F_{t \mid t+1}$ be the oneperiod forward price of the exchange rate, then the return of a currency long-forward contract is, $r_{\varphi \mid t+1}=\left(S_{t+1}-F_{t \mid t+1}\right) / S_{t}$, where the forward premium is denoted as $f_{t \mid t+1}=F_{t \mid t+1} / S_{t}-1$. In general, a foreign asset return given an arbitrary hedging strategy $\psi$ is:

$r_{t+1}^{H}=r_{t+1}-\psi r_{\varphi \mid t+1}$.

A simple hedging strategy is to unwind any passive currency holdings, i.e. $\psi=1$. In this case, the "fully" currency-hedged return can be written as:

$r_{t+1}^{H}=r_{t+1}^{*}+f_{t \mid t+1}+r_{t+1}^{*} s_{t+1}$.

The difference between the unhedged return $(\psi=0)$ and the fully hedged return $(\psi=1)$ is that the uncertain exchange rate component of the return is being substituted by the certain forward premium. Thus, it is expected that the volatility of hedged returns is smaller than that of unhedged returns. In contrast, the impact on the sample mean depends on the sign of the average forward premium and can be positive as well as negative in general. 
The unhedged as well as the fully hedged strategies are ad hoc currency management strategies. Jorion (1994), for instance, shows how an optimal currency strategy for a meanvariance investor can be analytically determined. Two components affect the optimal allocation with respect to currency risk exposure. The first is a speculative demand, determined by the risk-return ratio of the currency forward returns, and the second is a hedging demand, determined by the correlation structure to the core assets. Based on this, it is possible to show that an unhedged currency strategy $(\psi=0)$ is mean-variance optimal only, if currency forward returns have a zero expected return and are uncorrelated with the unhedged core assets. A comparison of equation (6) and $r_{\varphi \mid t+1}$ illustrates that this case is rather unrealistic, since both naturally contain the exchange rate component. An often proposed hedging strategy (Eun and Resnick, 1988; Perold and Schulman, 1988) is the full hedge ( $\psi=1$ ), and as can be shown, it would be justified also as an optimal hedge if the currency forward returns have a zero expected return and are uncorrelated with the core assets measured in the local currency. The fully-hedging strategy seems much more plausible to be mean-variance optimal. However, empirical studies such as Campbell et al. (2010) find that in general currency returns are often non-zero and correlated with some core assets measured in the local currency. For example, Campbell et al. (2010) find that an empirically meanvariance optimal hedge is close to a full hedge for international bonds. But there are some further gains for stock portfolios from overhedging positively correlated currencies and vice versa for negatively correlated currencies.

Nevertheless, studying fully hedged returns has the advantage that it is possible to dissect the diversification benefits from the pure core asset component almost without the influence of currency risk. Since we are primarily interested in the core assets, we focus on fully hedged returns.

\section{Data and Descriptive Statistics}

The empirical analysis of spanning is based on the nine largest securitized real estate markets. Even though their market share has decreased during the last 20 years due to the fast growth of securitized real estate markets around the world, these markets still cover around $75 \%$ of global market capitalization in securitized real estate markets and large parts of international stock market capitalization as well as major government bond markets. Thus, the market coverage is representative for US investors' investment universe. In addition to the US market, the markets in Australia, Canada, France, Hong Kong, Japan, the Netherlands, 
Singapore, and the UK are covered and thus, spread through economic and geographic regions. The sample period ranges from 1986 to 2009 and covers 24 years, which is a relatively extensive time period compared to previous studies.

For the national securitized real estate markets we use monthly data from Global Property Research (GPR), while the national stock markets are represented by the MSCI country indices. National government bond markets are represented by the 10-year bond indices from Merrill Lynch (ML-10y). Except for the bond indices for Hong Kong and Singapore, all indices are available for the whole sample period and thus, the three different asset indices for nine national markets build up a representative environment with 288 observations for each asset in each national market. Government bonds are not issued for large parts of the sample period for Singapore and there is no government bond market in Hong Kong. However, we consider these two real estate and stock markets in our analysis since both markets have a highly capitalized and well-developed real estate sector. Referring to the considered securitized real estate indices, Serrano and Hoesli (2009) conclude that the GPR indices are well suited both to measure the performance of the market and to evaluate portfolio performance. $^{3}$

The monthly returns from the total return indices are calculated as simple discrete returns. The average monthly returns and corresponding standard deviations are reported in Table I for unhedged and fully currency-hedged returns in US dollars since we will consider results from both sets of returns for spanning tests. The fully hedged returns are computed according to equation (8). We use foreign spot and forward exchange rates from Barclays Bank and WM Reuters available on Datastream.

Considering average returns for the US market, securitized real estate performs better than government bonds and slightly better than stocks, while government bonds show a much lower volatility than both stocks and real estate. Across national asset markets, Australia, France, Hong Kong, and Singapore show strong performance for all assets over the sample period while Japanese bonds and stocks and Canadian real estate have the lowest average returns. Compared to the US market, the performance of the international government bond and stock markets seems to be stronger at first glance. However, the US dollar has depreciated against many currencies in the last 24 years and thus, some of the return of the unhedged indices is attributed to currency gains. This finding is also confirmed when comparing 
unhedged and fully hedged returns. For all covered markets, fully currency-hedged returns are much lower than unhedged returns. At the same time, however, volatility also decreases substantially and is mostly comparable to the volatility of the corresponding US asset market. Thus, naïve currency hedging over the sample period results in lower returns and substantially lower volatility. Exceptions are, again, Hong Kong and Singapore. However, the reason for their high fully hedged returns compared to the other markets is straightforward. While the Hong Kong dollar is fixed against the US dollar, the Singapore dollar is freely traded but pegged by a basket of other currencies. Consequently, the statistics also show that return volatility does not substantially decrease for Hong Kong and Singapore when fully currencyhedged returns are considered. Related to the bond markets, their strong risk-adjusted performance is mainly driven by decreasing interest rates over a wide range of the sample period and particularly in the aftermath of the financial market turmoil at the end of the sample period.

Table I: Descriptive Statistics for Monthly Total Returns of the National Bond Market, Stock Market, and Securitized Real Estate Market Indices

\begin{tabular}{|c|c|c|c|c|c|c|c|c|c|c|c|c|}
\hline & \multicolumn{4}{|c|}{ Bonds (ML-10y) } & \multicolumn{4}{|c|}{ Stocks (MSCI) } & \multicolumn{4}{|c|}{ Real Estate (GPR) } \\
\hline & Mean & StD & Mean & StD & Mean & StD & Mean & StD & Mean & StD & Mean & StD \\
\hline \multicolumn{13}{|l|}{$\begin{array}{l}\text { National } \\
\text { Assets } \\
\end{array}$} \\
\hline US & 0.64 & 1.91 & & & 0.88 & 4.55 & & & 0.91 & 5.73 & & \\
\hline \multicolumn{13}{|c|}{$\begin{array}{l}\text { International } \\
\text { Assets }\end{array}$} \\
\hline & \multicolumn{2}{|c|}{ unhedged } & \multicolumn{2}{|c|}{ fully hedged } & \multicolumn{2}{|c|}{ unhedged } & \multicolumn{2}{|c|}{ fully hedged } & \multicolumn{2}{|c|}{ unhedged } & \multicolumn{2}{|c|}{ fully hedged } \\
\hline Australia & 0.99 & 3.86 & 0.59 & 1.96 & 1.26 & 6.69 & 0.86 & 4.81 & 1.21 & 5.92 & 0.81 & 4.37 \\
\hline Canada & 0.86 & 2.81 & 0.68 & 1.82 & 1.02 & 5.74 & 0.84 & 4.61 & 0.17 & 7.31 & -0.02 & 6.43 \\
\hline France & 0.91 & 3.41 & 0.64 & 1.49 & 1.10 & 6.17 & 0.83 & 5.88 & 1.05 & 5.67 & 0.79 & 4.52 \\
\hline Japan & 0.77 & 4.01 & 0.70 & 1.69 & 0.55 & 6.72 & 0.48 & 5.95 & 0.88 & 10.27 & 0.81 & 9.62 \\
\hline Netherlands & 0.82 & 3.50 & 0.60 & 1.32 & 1.11 & 5.54 & 0.88 & 5.48 & 0.84 & 4.91 & 0.62 & 4.12 \\
\hline UK & 0.82 & 3.50 & 0.56 & 1.90 & 0.92 & 5.18 & 0.66 & 4.73 & 0.88 & 6.79 & 0.62 & 6.20 \\
\hline Hong Kong & NA & & NA & & 1.39 & 8.10 & 1.41 & 8.09 & 1.74 & 10.85 & 1.75 & 10.84 \\
\hline Singapore & NA & & NA & & 1.18 & 7.85 & 1.15 & 7.32 & 1.99 & 11.90 & 1.96 & 11.33 \\
\hline
\end{tabular}

Notes: StD means standard deviation. The mean and standard deviation are presented in percent. The returns from a fully currency-hedged strategy are calculated as described in Section 4.

3 Serrano and Hoesli (2009) also show that correlation between global securitized real estate indices from different index providers are high and above 0.90 . 
Comparing returns and volatility from international real estate with those from the US securitized real estate market, it does not seem at first glance that international markets provide substantial diversification benefits, but correlations are completely neglected at this stage.

In addition to the risk and return characteristics, correlations also differ substantially between the three asset classes of the nine countries (see Appendix I). Comparing the correlation between currency-unhedged returns for the national markets within a given asset class, we find that the real estate markets are substantially less correlated with each other than the stock markets. This finding suggests that international diversification could work better for real estate than for stocks, as also proposed by Eichholtz (1996). A similar observation holds for the bond markets; they also reveal relatively low correlation with each other compared to the stock markets. In general, we find only slightly decreasing correlations within an asset class when currency risk is fully hedged.

In contrast, the correlations between two asset classes decrease notably when the currency risk is fully hedged. The decrease is most pronounced when comparing bonds with the other two asset classes. On average, currency hedging reduces correlation between bond and stock markets from 0.23 to 0.01 - between real estate and bonds, average correlation drops from 0.26 to 0.05 . Thus, returns are almost uncorrelated between stocks and bonds as well as between real estate and bonds when currency risk is fully hedged. In a similar way, but less vigorous, the correlations between the real estate markets and the stock markets are also reduced. However, exceptions are the markets in Hong Kong and Singapore. The crosscorrelations between their stock and real estate markets are around 0.90 (whether unhedged or fully hedged), and therefore, diversification benefits might be low from real estate when the corresponding stock markets of these two countries are already considered in a portfolio.

In summary, our findings seem to be reasonable. Currency hedging removes a US dollar risk present in any dollar/foreign currency pair and therefore, correlations between currencyunhedged returns contain an additional co-movement which is not caused by the core assets themselves. Accordingly, we expect more remarkable diversification benefits for fully hedged international returns than for unhedged returns. 


\section{Empirical Results on International Diversification Benefits}

\subsection{Domestic Diversification}

The empirical results from regression-based spanning and intersection tests are presented in Table II. Additionally, the maximum Sharpe ratio and the increase of the Sharpe ratio with respect to the benchmark assets are reported for each setting. First, in Panel A, we consider a US investor who holds US bonds and stocks, and considers expanding the investment universe with US securitized real estate. According to the $F$-test as well as the $W_{H A C}$-test for spanning, the null hypothesis of spanning cannot be rejected at any common significance level. This means that the investor cannot significantly improve her portfolio with US securitized real estate. ${ }^{4}$ The spanning tests are confirmed by the intersection tests for the global minimum variance portfolio as well as for the tangency portfolio. Also, the increase in the Sharpe ratio is close to zero.

\subsection{International Diversification with Unhedged Currency Risk}

Panel B of Table II reports the results from mean-variance spanning tests and intersection tests based on currency-unhedged returns of international assets. This means that in addition to bond, stock, and real estate market risk, currency risk exposure is still present in the portfolios. To be as strict and conservative as possible with the test results related to real estate, which is one of our main topics in the analysis, we first conduct mean-variance efficiency tests for bond and stock markets, before expanding the investment universe with international real estate. From a practical point of view, this procedure is not implausible, since most investors may add international bonds and stocks to their domestic mixed-asset portfolio before they consider investing in international real estate. Therefore, while spanning for international bonds is based on three benchmark assets (US bonds, US stocks, and US real estate), spanning on international real estate is based on a challenging benchmark of 17 assets (three US assets, six international bond markets, and eight international stock markets).

Spanning for international bonds is rejected at the $5 \%$ significance level. Considering specific points of the mean-variance frontier with intersection tests, the null hypothesis is rejected for the global minimum variance portfolio, but not for the tangency portfolio, at the $5 \%$ level.

4 The results from the $\mathrm{SDF}_{\mathrm{HAC}}$-based spanning and intersections tests are presented in Appendix II. 
The increase of the monthly Sharpe ratio in the last column by 0.06 indicates that the shift of the tangency portfolio is large in economic terms. Nevertheless, it is insignificant in statistical terms, reflecting high estimation uncertainty.

In the next row, we add international stocks to the investment menu. It is not possible to reject spanning at common levels for the $F$-test, though the $W_{\text {HAC }}$-test rejects at the $10 \%$ level. A closer look at the global minimum variance portfolio and the tangency portfolio shows that diversification benefits seem to be low especially in the region close to the tangency portfolio with p-values of 0.54 and 0.22 . Our results are strongly in line with the findings by Kan and Zhou (2008, p. 34) for the period from 1989 to 2006, which is similar to our sample: "By separating the sources of the rejection, we can conclude that there is strong evidence that the global minimum variance portfolio can be improved by the seven foreign stock market indices, but there is weaker evidence that the tangency portfolio can be improved.”

By contrast, the empirical results from the spanning tests and intersection tests are stronger for international real estate than for international stocks. This is confirmed by lower p-values for the spanning tests as well as for the intersection tests. The spanning and intersection tests for the global minimum variance portfolio are highly significant, while the results are not decisive for the tangency portfolio with a p-value for the $F$-test of 0.20 and for the $W_{H A C}$-test of 0.09 .

Finally, we test all 22 international assets against the benchmark of three US assets. The rejection of spanning provides evidence that international diversification yields substantial benefits. However, as the intersection tests indicate, the diversification benefits from international investing are only confirmed for the global minimum variance portfolio. Surprisingly, when turning to the tangency portfolio we find that even almost doubling the Sharpe ratio by investing internationally is not statistically significant at the $10 \%$ level. Hence, our results provoke the conclusion that the well-known home-bias in asset allocation decisions is rational for an investor who is interested in the tangency portfolio and considers currency-unhedged returns for investment decisions.

Summarizing the results from the several spanning and intersection tests for currencyunhedged returns, it can be stated that spanning is only weakly rejected for international stocks but that there are further diversification benefits from investing in international real estate. This result does not hold for the economically important region of the efficient frontier close to the tangency portfolio. However, at this moment one substantial risk factor in 
international portfolio diversification is not considered, namely the exposure to currency risk. Therefore, the offered benefits from a diversification across assets and across national markets may be misleading and the contribution of distinct assets may be biased by fluctuations in exchange rates generating additional volatility and/or returns.

\subsection{International Diversification with Fully Hedged Currency Risk}

Panel C of Table II provides mean-variance efficiency tests in the same ordering as in Panel B, but with fully currency-hedged international returns. The differences for international diversification in Panel C are overall remarkable and demonstrate the benefits of hedging currency risk exposure. Based on the benchmark of three US assets, all test statistics strongly reject spanning and intersection for international bonds. Also, the Sharpe ratio increases by $50 \%$ compared to a US mixed-asset portfolio. Even though the results on international stocks are improved, they are still ambivalent. Again, we can reject spanning and intersection for the global minimum variance portfolio, but not so for the tangency portfolio. Consistent with this result, the increase in the Sharpe ratio is similar to the increase observed for unhedged returns. This finding conjectures that both bond markets and stock markets are exposed to common risk factors. These risk factors may not differ substantially for international bonds and US assets on the one side and international stocks on the other.

Against this background, the statistical results from the spanning tests for international real estate are even more remarkable and in strong support of investments in international real estate yielding significant diversification benefits along the whole mean-variance efficient frontier. Spanning as well as intersection for the global minimum variance portfolio is rejected at the $1 \%$ level. Even the shift of the tangency portfolio is statistically significant with remarkable p-values below $10 \%$ and an increase of the Sharpe ratio from 0.34 to 0.41 .

Summarizing the results above, it can be stated - judged from our sample - that investors are well advised first to add international real estate to their asset allocation and second to consider currency risk-hedged strategies for asset allocation decisions. Particularly, the improvement of the tangency portfolio is not only economically huge, measured by the Sharpe ratio, but is also statistically significant, and leads to the conclusion that a home bias in asset allocation decisions is irrational, in contrast to the results from unhedged returns. Furthermore, and related to the systematically higher Sharpe ratios from fully currencyhedged returns, it may be conjectured that an optimal currency hedging strategy as suggested by Campbell et al. (2010a) yields further diversification benefits. 
Figure I presents a graphical illustration of the results discussed above for the fully currencyhedged portfolios. It sheds further light on our findings in the traditional representation of the mean-variance framework. Considering single asset markets, the group of the seven bond markets is relatively homogeneous concerning their risk-return profile, compared to the much more heterogeneous stock markets and real estate markets. The outward shift of the efficient frontier resulting from the addition of international bonds to a US mixed-asset portfolio is distinguishable, while there is only a modest outward shift in the mean-variance frontier when international stocks are included. This result is in line with the findings from spanning tests which are less significant, if at all, compared to bonds. Finally, there is a notable outward shift of the mean-variance efficient frontier when international real estate markets are taken into consideration for optimal portfolio allocation.

Table II: Results from Mean-Variance Spanning and Intersection Tests

\begin{tabular}{|c|c|c|c|c|c|c|c|c|}
\hline & \multicolumn{2}{|c|}{ Spanning } & \multicolumn{2}{|c|}{$\begin{array}{c}\text { Intersection } \\
\text { GMVP }\end{array}$} & \multicolumn{2}{|c|}{$\begin{array}{c}\text { Intersection } \\
\text { TP }\end{array}$} & \multirow[b]{2}{*}{ SR } & \multirow[b]{2}{*}{$\Delta \mathrm{SR}$} \\
\hline & $\boldsymbol{F}$ & $W_{\text {HAC }}$ & $F$ & $W_{\text {HAC }}$ & $F$ & $W_{H A C}$ & & \\
\hline \multicolumn{9}{|c|}{$\begin{array}{l}\text { Panel A: domestic diversification } \\
\text { benchmark portfolio: US bonds \& stocks }(\mathrm{K}=2)\end{array}$} \\
\hline US real estate $(\mathrm{N}=1)$ & 0.668 & 0.727 & 0.401 & 0.430 & 0.645 & 0.681 & 0.19 & 0.00 \\
\hline \multicolumn{9}{|c|}{$\begin{array}{l}\text { Panel B: international diversification - currency risk unhedged } \\
\text { benchmark portfolio: US assets }(\mathrm{K}=3)\end{array}$} \\
\hline intern. bonds $(\mathrm{K}=3, \mathrm{~N}=6)$ & 0.016 & 0.040 & 0.006 & 0.015 & 0.269 & 0.343 & 0.25 & 0.06 \\
\hline + intern. stocks $(\mathrm{K}=9, \mathrm{~N}=8)$ & 0.289 & 0.059 & 0.078 & 0.038 & 0.538 & 0.217 & 0.30 & 0.05 \\
\hline + intern. real estate $(\mathrm{K}=17, \mathrm{~N}=8)$ & 0.010 & 0.000 & 0.018 & 0.001 & 0.200 & 0.094 & 0.37 & 0.07 \\
\hline all intern. assets $(K=3, N=22)$ & 0.002 & 0.000 & 0.001 & 0.000 & 0.267 & 0.106 & 0.37 & 0.18 \\
\hline \multicolumn{9}{|c|}{$\begin{array}{l}\text { Panel C: international diversification - currency risk fully hedged } \\
\text { benchmark portfolio: US assets }(\mathrm{K}=3)\end{array}$} \\
\hline intern. bonds $(\mathrm{K}=3, \mathrm{~N}=6)$ & 0.000 & 0.000 & 0.000 & 0.000 & 0.044 & 0.033 & 0.29 & 0.10 \\
\hline + intern. stocks $(\mathrm{K}=9, \mathrm{~N}=8)$ & 0.038 & 0.000 & 0.006 & 0.000 & 0.515 & 0.290 & 0.34 & 0.05 \\
\hline + intern. real estate $(\mathrm{K}=17, \mathrm{~N}=8)$ & 0.000 & 0.000 & 0.000 & 0.000 & 0.095 & 0.066 & 0.41 & 0.08 \\
\hline all intern. assets $(\mathrm{K}=3, \mathrm{~N}=22)$ & 0.000 & 0.000 & 0.000 & 0.000 & 0.054 & 0.001 & 0.41 & 0.22 \\
\hline
\end{tabular}

Notes: The table reports p-values of spanning test statistics for a complete shift of the mean-variance frontier when $\mathrm{N}$ test assets are added to $\mathrm{K}$ benchmark assets. We also test for intersection, i.e., a shift at a single point of the mean-variance frontier, where TP is the tangency portfolio and GMVP is the global minimum variance portfolio. We proxy the risk-free rate by the US T-bill rate averaged over the sample period $(0.35 \%$ per month). SR is the Sharpe ratio when the test assets are included, andSR is the corresponding differential Sharpe ratio obtained by adding the test assets to the benchmark assets. The sample period ranges from 01/1986 to $12 / 2009$. 
Figure I: $\quad$ Mean-Variance Frontiers for Fully Currency-Hedged Returns

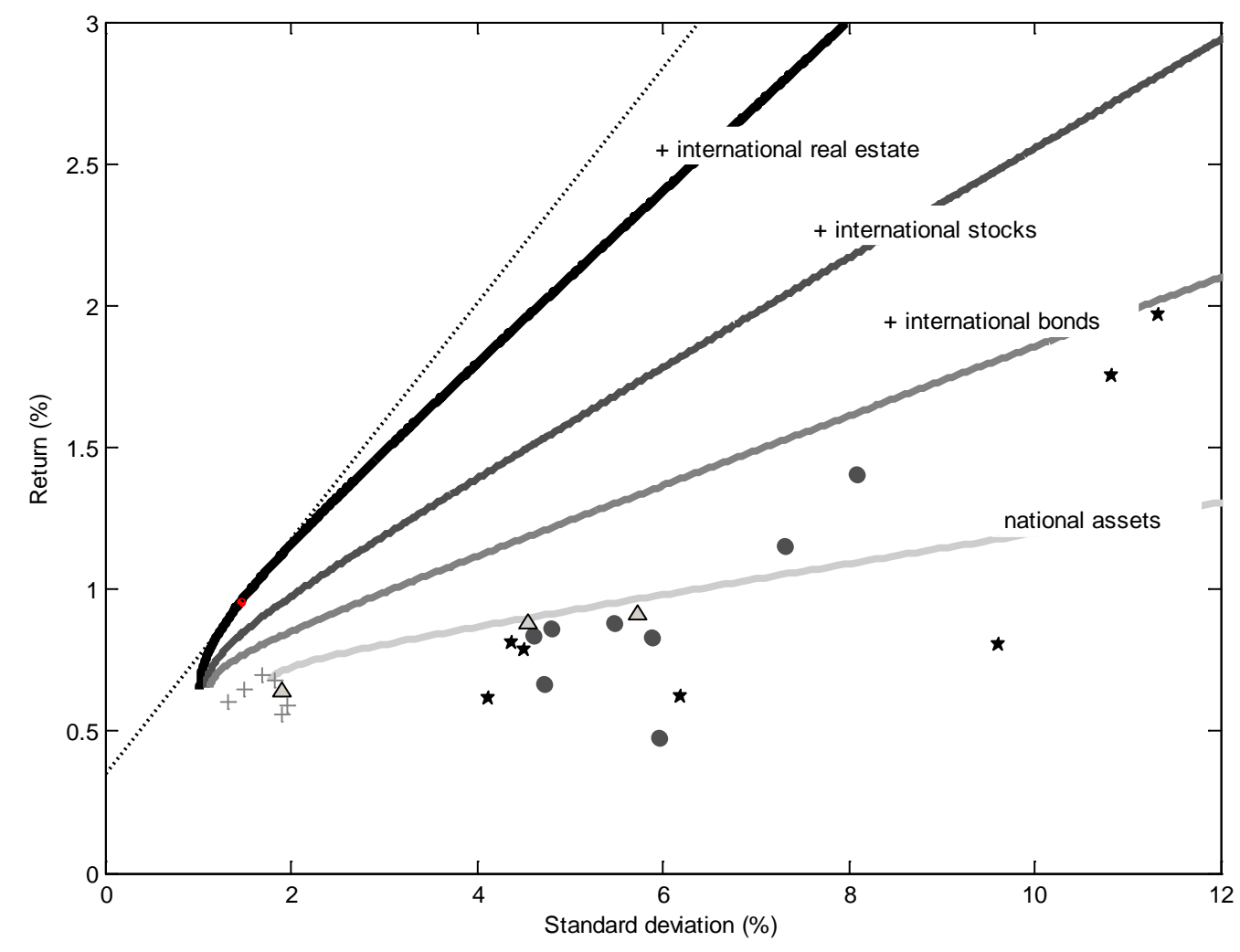

Notes: The figure plots the mean-variance efficient frontiers for national (US) assets (triangles) and frontiers successively augmented with fully hedged international bonds (crosses), international stocks (circles), and international real estate (stars). The sample covers monthly data, the period ranges from 01/1986 to $12 / 2009$.

\section{Robustness Tests}

\subsection{Results from Out-of-Sample Analysis}

So far, we have discussed in-sample tests of mean-variance portfolio efficiency. Following De Roon et al. (2003) and Eun et al. (2010) we reconsider our results with an out-of-sample analysis. For this purpose we use the first 100 observations of our sample to calculate meanvariance portfolio weights for the tangency portfolio and the global minimum variance portfolio. We hold these portfolios one period, collect the returns, move one month forward, and use the next 100 observations to obtain new optimal portfolio weights, and so forth. We do this at first considering only the benchmark assets and subsequently the benchmark assets together with the test assets. From this procedure we obtain a time-series of out-of-sample returns with and without the test assets, and can make use of the above described regression- 
based mean-variance intersection tests. We only test the tangency portfolio or the global minimum variance portfolio at once, and do not mix them in the out-of-sample analysis. The advantage of this procedure is that it allows us to incorporate short selling constraints and we can conduct a formal test comparable to the in-sample evaluation.

Panel A of Table III confirms the in-sample results for domestic diversification with US real estate. We do not find any significant out-of-sample improvement for the global minimum variance portfolio or the tangency portfolio. Turning to Panel B of Table III, we can broadly confirm the in-sample results for unhedged international returns. Only the international bond markets provide significant diversification benefits for the region close to the global minimum variance portfolio, and none of the assets improve the tangency portfolio in a significant way. Again, the results change dramatically when we consider fully currency-hedged returns instead of unhedged returns. With regard to the global minimum variance portfolio, all three asset classes provide additional diversification benefits to the national assets at the $5 \%$ level or below. Interestingly, the results change somewhat for the intersection tests of the tangency portfolio. In contrast to the in-sample analysis, international bonds do not pass the out-ofsample tests. Against this, the results for international stocks are slightly improved - they pass at least the heteroscedasticity-robust and autocorrelation-robust test at the $10 \%$ level with a pvalue of 0.09 . The intersection test for the tangency portfolio can also be rejected for international real estate at the $10 \%$ level for both tests. Overall, our out-of-sample tests confirms our in-sample results. Once currency-hedged returns are analyzed, international diversification works quite well with international bonds and stocks, and even better with international real estate considering the tangency portfolio. 
Table III: Results from Mean-Variance Spanning Tests in Out-of-Sample Setting

\begin{tabular}{|c|c|c|c|c|c|c|c|c|}
\hline & \multicolumn{2}{|c|}{$\begin{array}{c}\text { Intersection } \\
\text { GMVP }\end{array}$} & \multicolumn{2}{|c|}{$\begin{array}{c}\text { Intersection } \\
\text { TP } \\
\end{array}$} & \multicolumn{2}{|c|}{$\begin{array}{c}\text { Intersection } \\
\text { GMVP }\end{array}$} & \multicolumn{2}{|c|}{$\begin{array}{c}\text { Intersection } \\
\mathbf{T P} \\
\end{array}$} \\
\hline & $\boldsymbol{F}$ & $W_{H A C}$ & $F$ & $W_{H A C}$ & $\boldsymbol{F}$ & $W_{H A C}$ & $\boldsymbol{F}$ & $W_{H A C}$ \\
\hline \multicolumn{9}{|c|}{$\begin{array}{l}\text { Panel A: domestic diversification } \\
\text { benchmark portfolio: US bonds \& stocks }\end{array}$} \\
\hline US real estate & 0.161 & 0.338 & 0.262 & 0.286 & & & & \\
\hline
\end{tabular}

Panel B: international diversification

benchmark portfolio: US assets

international bonds

\begin{tabular}{lllllllll}
\multicolumn{4}{c}{ unhedged } & & \multicolumn{4}{c}{ fully hedged } \\
\cline { 1 - 4 } \cline { 6 - 8 } 0.000 & 0.006 & 0.411 & 0.352 & & 0.000 & 0.000 & 0.426 & 0.497 \\
0.799 & 0.794 & 0.605 & 0.300 & & 0.007 & 0.005 & 0.111 & 0.088 \\
0.771 & 0.777 & 0.835 & 0.814 & & 0.010 & 0.033 & 0.058 & 0.089 \\
0.001 & 0.001 & 0.855 & 0.840 & & 0.000 & 0.000 & 0.017 & 0.056
\end{tabular}

Notes: The table reports p-values from out-of-sample test results for mean-variance intersections tests. We proxy the risk-free rate by the US T-bill rate averaged over the sample period. The sample period ranges from $01 / 1986$ to $12 / 2009$. 


\subsection{Short Selling Constraints}

According to Bris et al. (2007), short selling is in principle allowed and practiced in all nine countries covered in our analysis for the major time span of our sample period. Nevertheless, in this subsection we include market frictions and/or investment restrictions (e.g. for pension funds), in form of short selling constraints to the mean-variance efficiency tests, as a further robustness check.

Table IV reports intersection tests for the global minimum variance and the tangency portfolio, in-sample as well as out-of-sample, in the same order as before. Again, Panel A verifies our preceding results. We do not find any highly significant diversification gains from domestic diversification with US real estate in any setting.

The in-sample results, with regard to the global minimum variance portfolio, confirm diversification benefits from international investing even under short selling constraints. However, with regard to international real estate, and in contrast to the results in Table II, we can only reject intersection at the $10 \%$ level with fully hedged returns. This seems to stress the importance of using fully hedged returns also under the presence of short selling constraints. In further contrast to our results without short selling constraints, we can decisively reject intersection in-sample for the tangency portfolio only for the international bonds, even in the fully hedged scenario.

It is remarkable that the out-of-sample results in Table IV are again broadly in line with the out-of-sample results without short selling restrictions. We find significant diversification benefits at the $10 \%$ level for the global minimum variance portfolio from adding all three fully currency-hedged asset classes. Furthermore, international real estate is confirmed to significantly improve the tangency portfolio with p-values of 0.03 and 0.08 for the HAC-test respectively. 
Table IV: Results from Mean-Variance Spanning Tests with Short Selling Constraints

\begin{tabular}{|c|c|c|c|c|c|c|c|c|c|}
\hline & \multicolumn{5}{|c|}{ In-Sample Tests } & \multicolumn{4}{|c|}{ Out-of-Sample Tests } \\
\hline & \multicolumn{2}{|c|}{$\begin{array}{c}\text { Intersection } \\
\text { GMVP }\end{array}$} & \multicolumn{2}{|c|}{$\begin{array}{c}\text { Intersection } \\
\text { TP }\end{array}$} & \multirow[b]{2}{*}{$S R$} & \multicolumn{2}{|c|}{$\begin{array}{c}\text { Intersection } \\
\text { MVP }\end{array}$} & \multicolumn{2}{|c|}{$\begin{array}{c}\text { Intersection } \\
\text { TP } \\
\end{array}$} \\
\hline & $W_{S}$ & $W_{S \mid H A C}$ & $W_{S}$ & $W_{S \mid \text { HAC }}$ & & $W_{S}$ & $W_{S \mid \text { HAC }}$ & $W_{S}$ & $W_{S \mid \text { HAC }}$ \\
\hline \multicolumn{10}{|c|}{$\begin{array}{l}\text { Panel A: domestic diversification } \\
\text { benchmark portfolio: US bonds \& stocks }\end{array}$} \\
\hline US real estate & 0.198 & 0.247 & 0.321 & 0.343 & 0.19 & 0.047 & 0.129 & 0.284 & 0.304 \\
\hline \multicolumn{10}{|c|}{$\begin{array}{l}\text { Panel B: international diversification } \\
\text { benchmark portfolio: US assets }\end{array}$} \\
\hline & \multicolumn{5}{|c|}{ unhedged } & \multicolumn{4}{|c|}{ unhedged } \\
\hline intern. bonds & 0.000 & 0.004 & 0.011 & 0.296 & 0.23 & 0.012 & 0.006 & 0.499 & 0.499 \\
\hline + intern. stocks & 0.014 & 0.051 & 0.597 & 0.710 & 0.24 & 0.487 & 0.481 & 0.302 & 0.316 \\
\hline + intern. real estate & 0.391 & 0.427 & 0.849 & 0.827 & 0.25 & 0.499 & 0.498 & 0.086 & 0.117 \\
\hline all intern. assets & 0.000 & 0.034 & 0.001 & 0.702 & 0.25 & 0.057 & 0.030 & 0.343 & 0.364 \\
\hline & \multicolumn{5}{|c|}{ fully hedged } & \multicolumn{4}{|c|}{ fully hedged } \\
\hline intern. bonds & 0.000 & 0.000 & 0.001 & 0.054 & 0.28 & 0.000 & 0.000 & 0.027 & 0.034 \\
\hline + intern. stocks & 0.000 & 0.001 & 0.007 & 0.298 & 0.30 & 0.000 & 0.000 & 0.375 & 0.387 \\
\hline + intern. real estate & 0.039 & 0.071 & 0.682 & 0.699 & 0.31 & 0.089 & 0.100 & 0.034 & 0.076 \\
\hline all intern. assets & 0.000 & 0.000 & 0.001 & 0.273 & 0.31 & 0.000 & 0.000 & 0.006 & 0.006 \\
\hline
\end{tabular}

Notes: The table reports p-values from intersection test results with short selling constraints, in-sample and outof-sample. $\mathrm{W}_{\mathrm{S}}$ is the Wald test under short selling constraints. We proxy the risk-free rate by the US Tbill rate averaged over the sample period. The sample period ranges from 01/1986 to 12/2009.

\subsection{Time Trends in the Diversification Benefits from Real Estate}

This section examines if the previously found diversification benefits from international assets, especially from international real estate, contain any time trend. It is well documented in the literature that linkages between assets and national markets are time-varying, that financial markets have become more integrated in the last decades, and that, as a consequence, international diversification benefits are possibly decreasing (e.g. Ang and Bekaert, 2002; Bekaert and Harvey, 1995; Bekaert et al., 2005; Goetzmann et al., 2005; Longin and Solnik, 1995 and 2001). Related to real estate in a mixed-asset context, Sa-Aadu et al. (2010) find that real estate - similar to precious metals - provides good hedging characteristics against adverse shocks to consumption growth opportunities and in the bad state of the economy. 
To realize our analysis, we focus on the tangency portfolio ${ }^{5}$ and construct forward-rolling subsamples of 100-months, proceeding in one-month intervals. Accordingly, the first of 189 subsamples spans the time period from 01/1986 to 04/1994 and the last subsample the period from 09/2001 to 12/2009. For each subsample, we follow the same order as in Table II. First, we add international bonds to a benchmark of three national (US) assets, and collect the differential Sharpe ratio against to the pure benchmark portfolio. Subsequently, we treat international bonds and the national assets as benchmark assets, and add international stocks as test assets. In the same way, we next add international real estate as test assets, and finally we treat all three international asset classes as test assets together against the benchmark containing only national assets. From this procedure, we obtain a time series of differential Sharpe ratios of international assets against national assets, and can control for which part of the diversification benefits can be attributed to which asset class.

The contribution to the differential Sharpe ratio of the augmented portfolio with international assets is visualized over time in Figure II, and Table V presents the according statistics. Our discussion mainly focuses on the results from fully currency-hedged returns. As can be seen, the international bonds deliver steadily rising diversification benefits, with a highly significant time trend. This is not surprising, since long-term bond prices have been rising in the past decades due to falling long-term yields. The, in historical terms, exceptional risk-adjusted performance of long-term bonds over the past years has already been discussed in the data section of the paper (see also Table I). However, Figure II reveals that diversification benefits from long-term bonds can be quite low in an economic environment with globally high or rising long-term yields, as in the late 1980s or early 1990s covered in the first 40 subperiods. ${ }^{6}$ The comparison to the unhedged statistics also shows that currency hedging has a rather dramatic impact on the diversification benefits from international bonds.

The diversification benefits measured in economic terms by differential Sharpe ratios from international stocks (visualized as the area between the two dotted lines in Figure II) seem to be oscillating. The differential Sharpe ratios are rather large in subsamples with mainly bullish markets (mid 1990s, mid 2000s) and decrease in subsamples with mainly bearish markets (late 1980s, during the aftermath of the dotcom bubble burst in 2002, and most

5 Note that rejection of intersection for the tangency portfolio is shown to be a more challenging test than for the global minimum variance portfolio.

6 Bond risk premias declined in the recent years, driving up ex post returns (Campbell et al. 2010b). Hence, we find extraordinary risk-return characteristics for bonds in our sample, in contrast to longer historical comparisons (Palazzo and Nobili, 2010). 
distinctively in the aftermath of the most recent global financial market turmoil). The time trend regressions indicate that there is a small but significant time trend of falling differential Sharpe ratios for international stocks.

Similarly, we find oscillating diversification benefits from international real estate, in addition to the benefits from the stock markets. The differential Sharpe ratios of international real estate are on average larger than those from the stock markets. However, they decrease strongly in the subsamples ending after 2008. In line with this, we find that all 151 significant differential Sharpe ratios of the 189 subsamples end before 2008. The strong decrease of diversification benefits at the end of the time series also explains the significant negative time trend provided by the regression in Table V. We see this as evidence that international real estate provides substantial diversification benefits in good times, less but still significant benefits in bad times, but turns insignificant in very bad times, as during the financial turmoil of 2008. Clearly, international bonds can contribute most to the portfolio performance in such very bad times, as is shown at the end of the sample period in the two panels of Figure II. However, this period is also characterized by substantial interest rate decreases by the central banks all over the world. Therefore, it is difficult to judge how representative this finding is for other periods, i.e., hot periods which are not accompanied by decreasing interest rates.

Finally, measuring international diversification in terms of all three asset classes together, we find an insignificant time trend when the currency risk is fully hedged. The diversification benefits seem to be rather steadily swinging without any trend, whereas in some periods one or another asset class contributes more or less to the differential Sharpe ratio against a national portfolio. This does not hold regarding the currency risk-unhedged counterpart. In this setting, we find a significant decreasing time trend which may lead to the potentially misleading conclusion that diversification benefits from international investing are decreasing over time. 
Table V: $\quad$ Statistics for Time Trends in the Differential Sharpe Ratio

\begin{tabular}{|c|c|c|c|c|c|c|}
\hline \multicolumn{7}{|c|}{ Descriptive statistics of $\Delta \mathrm{SR}_{\mathrm{t}}$} \\
\hline & Mean & StD & sign/obs & Mean & StD & sign/obs \\
\hline & \multicolumn{3}{|c|}{ unhedged } & \multicolumn{3}{|c|}{ fully hedged } \\
\hline international bonds & 0.09 & 0.04 & $186 / 189$ & 0.17 & 0.09 & $189 / 189$ \\
\hline + international stocks & 0.14 & 0.05 & $134 / 189$ & 0.13 & 0.06 & $167 / 189$ \\
\hline + international real estate & 0.18 & 0.04 & $188 / 189$ & 0.18 & 0.08 & $151 / 189$ \\
\hline all international assets & 0.41 & 0.08 & $189 / 189$ & 0.47 & 0.08 & $189 / 189$ \\
\hline \multicolumn{7}{|c|}{ Time trend regressions: $\Delta \mathrm{SR}_{\mathrm{t}}=\alpha+\beta$ time $_{\mathrm{t}}+\varepsilon_{\mathrm{t}}$} \\
\hline & $\boldsymbol{\alpha}$ & $\boldsymbol{\beta}$ & adj. $R^{2}$ & $\alpha$ & $\boldsymbol{\beta}$ & adj. $\mathbf{R}^{2}$ \\
\hline & \multicolumn{3}{|c|}{ unhedged } & \multicolumn{3}{|c|}{ fully hedged } \\
\hline international bonds & 0.0919 & 0.0000 & 0.00 & 0.0515 & 0.0012 & 0.60 \\
\hline t-stats $(\mathrm{HAC})$ & $(7.45)$ & $(-0.24)$ & & $(5.00)$ & $(11.11)$ & \\
\hline + international stocks & 0.1818 & -0.0004 & 0.16 & 0.1769 & -0.0005 & 0.24 \\
\hline t-stats $(\mathrm{HAC})$ & $(13.97)$ & $(-3.71)$ & & $(12.42)$ & $(-4.80)$ & \\
\hline + international real estate & 0.1991 & -0.0002 & 0.08 & 0.2629 & -0.0009 & 0.42 \\
\hline t-stats ${ }_{(\mathrm{HAC})}$ & (19.59) & $(-2.37)$ & & (13.44) & $(-6.33)$ & \\
\hline all international assets & 0.4728 & -0.0007 & 0.19 & 0.4913 & -0.0002 & 0.02 \\
\hline t-stats $_{(\mathrm{HAC})}$ & $(28.05)$ & $(-3.90)$ & & $(22.02)$ & $(-1.23)$ & \\
\hline
\end{tabular}

Notes: The table reports descriptive statistics and time trend regressions of differential Sharpe ratios $(\Delta \mathrm{SR})$ of the tangency portfolio between the augmented portfolio and a benchmark portfolio containing national (US) assets. For each set, we compute the Sharpe ratio from 100-month rolling windows, resulting in 189 observations (obs) obtained from the sample period from 01/1986 to 12/2009, where sign refers to the number of significant $\Delta \mathrm{SR}$ at the $10 \%$ level under the $\mathrm{W}_{\mathrm{HAC}}$ test statistic for intersection. Regression t-statistics in parentheses are robust against heteroscedasticity and serial autocorrelation (Newey-West, three lags).

Figure II: Time Trends in the Differential Sharpe Ratio
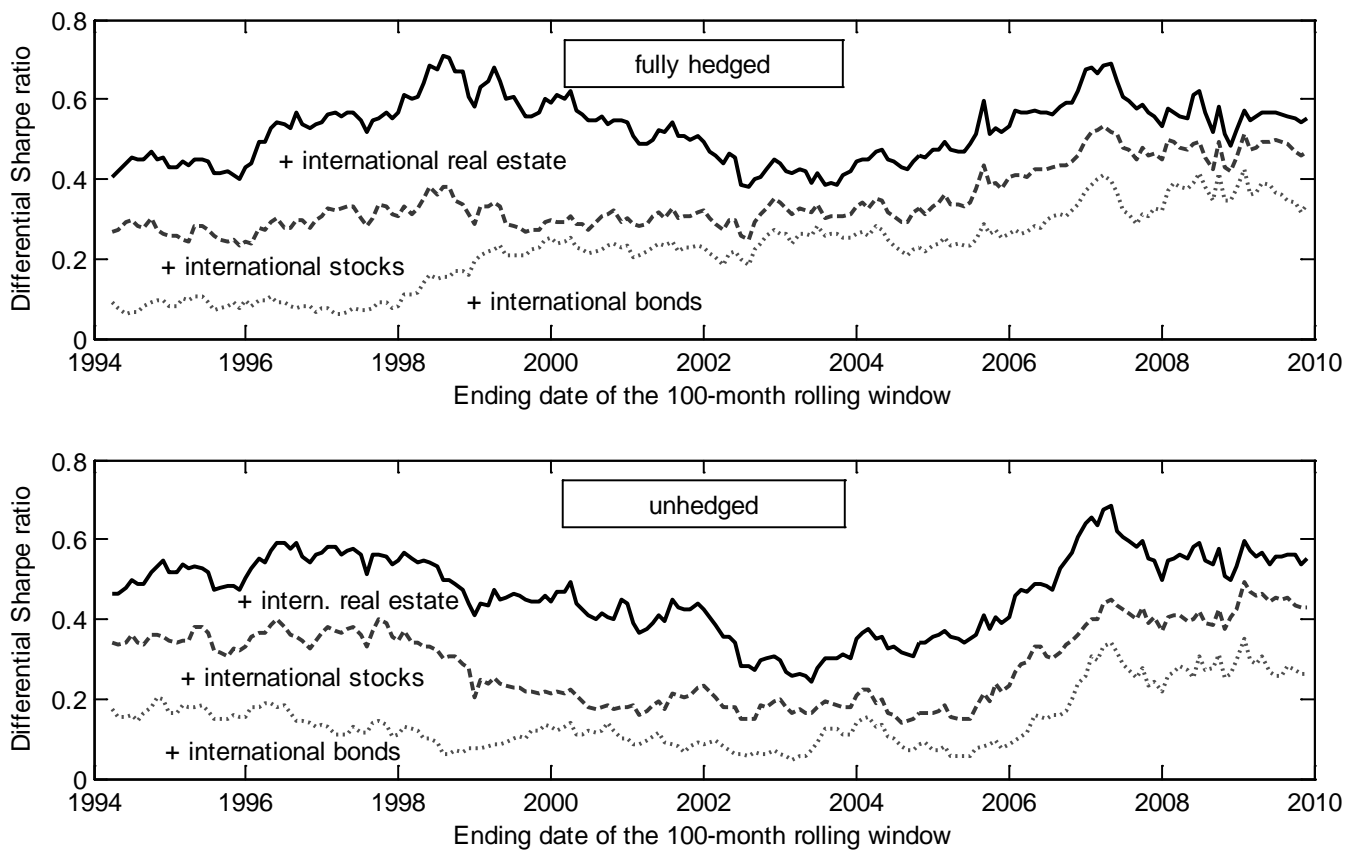


\section{Conclusion}

In this paper, we have investigated investors' benefits from international diversification for a sample of nine countries in a mixed-asset portfolio context including international bonds, stocks, and international securitized real estate, in particular from the perspective of a US investor. Furthermore, we have considered the impact of hedging currency risk exposure, which is often neglected in the analysis of international diversification benefits but can substantially influence the results.

Our main findings are as follows. First, for a US investor invested in a diversified US mixedasset portfolio, and who does consider currency risk-unhedged assets, we can reject the spanning hypothesis for international bonds, stocks and real estate. However, the intersection tests for the tangency portfolio cannot be rejected, indicating only insignificant improvements of the maximum attainable Sharpe ratio. Second, by contrast, adding international assets to the investment universe when a simple full hedge is applied, results in significant diversification benefits from international bonds and real estate also for the tangency portfolio, but still remains insignificant for international stocks. In the relevant literature, it is well documented that investors mainly invest in their domestic market and that investments are thus home-biased. By contrast, the empirical results from fully currency-hedged international assets suggest that investors are well advised to expand their investment universe from their domestic assets to international assets, because they will be rewarded by significant gains from international investments. Third, our results are mainly robust to out-of-sample analysis and when investment frictions in form of short selling constraints are taken into account. In general, it is shown that neglecting international real estate in an international mixed-asset portfolio results in a loss of diversification opportunities. Fourth, the analysis of time trends in the diversification benefits provided by international real estate shows stable and significant results for the subsamples before 2008, while the period afterwards is characterized by financial market turmoil, which has a well-known negative impact on diversification opportunities. Therefore, the analysis provides no final answer to the question of whether diversification benefits from international real estate decrease over time due to increasing financial market integration, as is well documented for international stocks. However, there is some empirical evidence that the benefits from real estate are only diminished during untypical and hot market periods such as in 2008, and that they are given during more calm and common periods. 
Since the conducted analysis is based on historical data and applies a static or myopic framework, further research could contribute to answering the question of which variables are a good predictor for investment decisions and if the diversification benefits are still significant in a dynamic, time-varying framework. Furthermore, related to hedging currency risk exposure and the shown evidence that currency hedging matters for portfolio optimization, an analysis on optimal currency hedging will provide interesting insight into this topic. Against the background of the recent financial crisis in particular, it is also an interesting topic for future research to construct and conduct spanning tests in a downside risk framework. 


\section{Appendix}

Appendix I: Correlation between Currency-Unhedged and Fully Hedged Returns across Assets and Countries

\begin{tabular}{|c|c|c|c|c|c|c|c|c|c|c|c|c|c|c|c|c|c|c|c|c|c|c|c|c|c|}
\hline & B-US & S-US & R-US & B-AU & B-CA & B-FR & B-JP & B-NL & B-UK & S-AU & S-CA & S-FR & S-JP & S-NL & S-UK & S-HK & S-SG & R-AU & R-CA & R-FR & R-JP & R-NL & R-UK & R-HK & R-SG \\
\hline B-US & & 0.05 & 0.07 & 0.24 & 0.47 & 0.49 & 0.30 & 0.47 & 0.36 & -0.12 & -0.03 & 0.03 & 0.05 & -0.03 & 0.02 & -0.06 & -0.10 & -0.02 & 0.05 & 0.14 & 0.10 & 0.08 & 0.03 & -0.07 & -0.05 \\
\hline S-US & 0.05 & & 0.60 & 0.32 & 0.39 & 0.01 & -0.02 & -0.02 & 0.05 & 0.58 & 0.76 & 0.66 & 0.38 & 0.73 & 0.72 & 0.55 & 0.63 & 0.51 & 0.43 & 0.31 & 0.23 & 0.35 & 0.44 & 0.47 & 0.57 \\
\hline R-US & 0.07 & 0.60 & & 0.31 & 0.33 & 0.14 & 0.00 & 0.11 & 0.08 & 0.44 & 0.50 & 0.46 & 0.29 & 0.50 & 0.49 & 0.36 & 0.45 & 0.50 & 0.49 & 0.49 & 0.25 & 0.52 & 0.55 & 0.31 & 0.41 \\
\hline B-AU & 0.52 & 0.10 & 0.14 & & 0.51 & 0.36 & 0.14 & 0.34 & 0.32 & 0.72 & 0.47 & 0.32 & 0.25 & 0.37 & 0.41 & 0.37 & 0.31 & 0.70 & 0.35 & 0.38 & 0.19 & 0.36 & 0.38 & 0.33 & 0.27 \\
\hline B-CA & 0.72 & 0.18 & 0.11 & 0.53 & & 0.37 & 0.15 & 0.37 & 0.36 & 0.34 & 0.58 & 0.32 & 0.26 & 0.37 & 0.36 & 0.31 & 0.27 & 0.38 & 0.49 & 0.33 & 0.20 & 0.37 & 0.27 & 0.26 & 0.25 \\
\hline B-FR & 0.61 & 0.03 & 0.07 & 0.44 & 0.49 & & 0.52 & 0.97 & 0.66 & 0.07 & 0.04 & 0.36 & 0.24 & 0.27 & 0.26 & 0.05 & 0.03 & 0.21 & 0.10 & 0.59 & 0.17 & 0.50 & 0.28 & 0.07 & 0.06 \\
\hline B-JP & 0.34 & 0.01 & 0.10 & 0.22 & 0.34 & 0.31 & & 0.55 & 0.45 & -0.05 & -0.01 & 0.18 & 0.44 & 0.12 & 0.16 & 0.05 & -0.01 & 0.03 & 0.03 & 0.30 & 0.35 & 0.21 & 0.18 & 0.08 & 0.06 \\
\hline B-NL & 0.63 & -0.02 & 0.03 & 0.47 & 0.52 & 0.88 & 0.35 & & 0.67 & 0.06 & 0.04 & 0.33 & 0.24 & 0.26 & 0.24 & 0.03 & 0.02 & 0.20 & 0.12 & 0.57 & 0.15 & 0.51 & 0.26 & 0.05 & 0.05 \\
\hline B-UK & 0.57 & 0.07 & 0.07 & 0.44 & 0.58 & 0.63 & 0.37 & 0.66 & & 0.14 & 0.10 & 0.26 & 0.30 & 0.21 & 0.46 & 0.07 & 0.02 & 0.22 & 0.19 & 0.37 & 0.27 & 0.33 & 0.43 & 0.07 & 0.02 \\
\hline S-AU & -0.14 & 0.59 & 0.43 & 0.23 & -0.01 & -0.06 & -0.11 & -0.03 & 0.02 & & 0.67 & 0.51 & 0.38 & 0.58 & 0.62 & 0.57 & 0.59 & 0.79 & 0.49 & 0.36 & 0.25 & 0.41 & 0.48 & 0.49 & 0.50 \\
\hline S-CA & -0.04 & 0.78 & 0.46 & 0.10 & 0.14 & -0.07 & -0.03 & -0.07 & 0.00 & 0.61 & & 0.60 & 0.43 & 0.67 & 0.65 & 0.62 & 0.62 & 0.56 & 0.63 & 0.37 & 0.26 & 0.40 & 0.40 & 0.54 & 0.55 \\
\hline S-FR & -0.10 & 0.69 & 0.42 & 0.00 & 0.01 & 0.13 & 0.03 & 0.04 & 0.09 & 0.53 & 0.62 & & 0.48 & 0.80 & 0.71 & 0.46 & 0.47 & 0.49 & 0.41 & 0.63 & 0.30 & 0.53 & 0.44 & 0.38 & 0.41 \\
\hline S-JP & -0.05 & 0.45 & 0.36 & -0.05 & 0.07 & 0.00 & 0.04 & -0.04 & 0.02 & 0.42 & 0.47 & 0.48 & & 0.47 & 0.50 & 0.33 & 0.38 & 0.35 & 0.33 & 0.43 & 0.78 & 0.38 & 0.39 & 0.30 & 0.36 \\
\hline S-NL & -0.17 & 0.74 & 0.45 & 0.05 & 0.02 & -0.03 & -0.07 & -0.06 & -0.02 & 0.61 & 0.67 & 0.78 & 0.47 & & 0.78 & 0.53 & 0.57 & 0.56 & 0.48 & 0.56 & 0.29 & 0.59 & 0.54 & 0.46 & 0.49 \\
\hline S-UK & -0.02 & 0.78 & 0.50 & 0.15 & 0.11 & 0.05 & 0.01 & 0.01 & 0.20 & 0.63 & 0.66 & 0.71 & 0.44 & 0.78 & & 0.56 & 0.59 & 0.57 & 0.48 & 0.50 & 0.32 & 0.48 & 0.72 & 0.48 & 0.52 \\
\hline S-HK & -0.06 & 0.55 & 0.36 & 0.10 & 0.05 & -0.03 & -0.02 & -0.03 & 0.00 & 0.54 & 0.60 & 0.45 & 0.34 & 0.51 & 0.56 & & 0.74 & 0.50 & 0.37 & 0.27 & 0.13 & 0.27 & 0.36 & 0.93 & 0.68 \\
\hline S-SG & -0.13 & 0.63 & 0.44 & -0.03 & -0.03 & -0.11 & -0.06 & -0.12 & -0.07 & 0.59 & 0.61 & 0.48 & 0.42 & 0.57 & 0.63 & 0.73 & & 0.48 & 0.39 & 0.32 & 0.18 & 0.36 & 0.41 & 0.71 & 0.89 \\
\hline R-AU & 0.00 & 0.45 & 0.47 & 0.29 & 0.08 & 0.06 & $\begin{array}{l}-0.02 \\
\end{array}$ & 0.07 & 0.09 & 0.60 & 0.37 & 0.39 & 0.29 & 0.44 & 0.46 & 0.39 & 0.37 & & 0.47 & 0.45 & 0.27 & 0.50 & 0.52 & 0.43 & 0.39 \\
\hline R-CA & 0.06 & 0.37 & 0.44 & 0.12 & 0.16 & 0.05 & 0.07 & 0.08 & 0.06 & 0.42 & 0.49 & 0.35 & 0.33 & 0.40 & 0.37 & 0.30 & 0.33 & 0.35 & & 0.38 & 0.32 & 0.43 & 0.41 & 0.33 & 0.34 \\
\hline R-FR & 0.01 & 0.39 & 0.54 & 0.08 & 0.03 & 0.11 & 0.03 & 0.05 & 0.01 & 0.35 & 0.38 & 0.54 & 0.41 & 0.45 & 0.44 & 0.29 & 0.34 & 0.37 & 0.38 & & 0.31 & 0.78 & 0.53 & 0.25 & 0.29 \\
\hline R-JP & 0.04 & 0.26 & 0.28 & 0.01 & 0.08 & 0.05 & 0.07 & 0.00 & 0.08 & 0.25 & 0.25 & 0.28 & 0.74 & 0.28 & 0.23 & 0.12 & 0.18 & 0.23 & 0.33 & 0.30 & & 0.29 & 0.29 & 0.16 & 0.21 \\
\hline R-NL & -0.09 & 0.43 & 0.54 & -0.02 & 0.00 & 0.01 & -0.07 & -0.02 & -0.06 & 0.41 & 0.39 & 0.45 & 0.35 & 0.53 & 0.43 & 0.29 & 0.38 & 0.40 & 0.39 & 0.66 & 0.29 & & 0.54 & 0.27 & 0.33 \\
\hline R-UK & 0.00 & 0.48 & 0.58 & 0.20 & 0.10 & 0.13 & 0.06 & 0.12 & 0.18 & 0.46 & 0.38 & 0.40 & 0.33 & 0.50 & 0.66 & 0.36 & 0.41 & 0.45 & 0.34 & 0.51 & 0.21 & 0.52 & & 0.32 & 0.36 \\
\hline R-HK & -0.07 & 0.47 & 0.31 & 0.06 & 0.04 & -0.03 & -0.04 & -0.03 & -0.02 & 0.45 & 0.53 & 0.36 & 0.28 & 0.42 & 0.47 & 0.93 & 0.68 & 0.31 & 0.28 & 0.25 & 0.14 & 0.26 & 0.31 & & 0.68 \\
\hline R-SG & -0.06 & 0.57 & 0.40 & -0.01 & 0.05 & -0.04 & -0.04 & -0.06 & -0.05 & 0.50 & 0.55 & 0.40 & 0.35 & 0.48 & 0.56 & 0.67 & 0.87 & 0.28 & 0.30 & 0.29 & 0.19 & 0.34 & 0.37 & 0.66 & \\
\hline
\end{tabular}

Notes: The lower part of the table shows correlation for fully currency-hedged returns, while correlations of currency-unhedged returns are shown in the upper part. X-XX indicates the asset and the national market. B, S, and R indicate bond market, stock market, and real estate market, respectively. The countries are indicated as follows: AU - Australia, CA - Canada, FR - France, HK - Hong Kong, JP - Japan, NL - the Netherlands, SG - Singapore, UK - United Kingdom, US - United States. Correlation coefficients above 0.50 are highlighted grey. 
Appendix II: Results from Stochastic Discount Factor-Based Mean-Variance Spanning and Intersection Tests

\begin{tabular}{|c|c|c|c|c|c|c|}
\hline & \multicolumn{3}{|c|}{$\boldsymbol{S D} \boldsymbol{F}_{H A C}$} & \multicolumn{3}{|c|}{$S \boldsymbol{D} \boldsymbol{F}_{H A C}$} \\
\hline & SPAN & GMVP & TP & SPAN & GMVP & TP \\
\hline \multicolumn{7}{|c|}{$\begin{array}{l}\text { Panel A: national diversification } \\
\text { benchmark portfolio: US bonds \& stocks }(K=2)\end{array}$} \\
\hline US real estate $(\mathrm{N}=1)$ & 0.765 & 0.468 & 0.691 & & & \\
\hline \multicolumn{7}{|c|}{$\begin{array}{l}\text { Panel B: international diversification } \\
\text { benchmark portfolio: US assets }(K=3)\end{array}$} \\
\hline & \multicolumn{3}{|c|}{ unhedged } & \multicolumn{3}{|c|}{ fully hedged } \\
\hline intern. bonds $(\mathrm{N}=6)$ & 0.007 & 0.005 & 0.271 & 0.000 & 0.000 & 0.121 \\
\hline + intern. stocks $(\mathrm{K}=9, \mathrm{~N}=8)$ & 0.032 & 0.025 & 0.272 & 0.007 & 0.013 & 0.296 \\
\hline + intern. real estate $(\mathrm{K}=17, \mathrm{~N}=8)$ & 0.000 & 0.000 & 0.050 & 0.000 & 0.000 & 0.041 \\
\hline all intern. assets $(\mathrm{K}=3, \mathrm{~N}=22)$ & 0.000 & 0.000 & 0.040 & 0.000 & 0.000 & 0.006 \\
\hline
\end{tabular}

Notes: The table accomplishes the regression-based spanning tests of Table II, and reports p-values of the stochastic discount factor-based spanning test statistic (SPAN) for a complete shift of the mean-variance frontier when $\mathrm{N}$ test assets are added to $\mathrm{K}$ benchmark assets. We also report results of intersection tests, that is a shift at a single point of the mean-variance frontier, where TP is the tangency portfolio and GMVP is the global minimum variance portfolio. We proxy the risk-free rate by the US T-bill rate averaged over the sample period ( $0.35 \%$ per month). The tests are errors-in-variables adjusted as proposed by Kan and Zhou (2008). The sample period ranges from 01/1986 to 12/2009.

\section{Appendix III: Stochastic Discount Factor-Based Tests}

Bekaert and Urias (1996) propose an alternative to the regression-based test of spanning and intersection using the SDF perspective. They start with the central asset pricing equation which should hold for any asset by a no-arbitrage condition, and thus for the $N+K$ returns $r_{t}$ as well:

$$
E\left[m_{t+1}\left(1+r_{t+1}\right)\right]=1_{N+K},
$$

where $m_{t+1}$ is a SDF. As shown by Hansen and Jagannathan (1991), the linear projection of $m_{t+1}$ on the $N+K$ asset returns gives the lower bound of the variance of all SDFs satisfying the asset pricing equation above, given an expected value of the SDF $v=E\left(m_{t+1}\right)$. This SDF is solely constructed from the assets being priced:

$$
m_{t+1}^{*}(v)=v+b(v)^{\prime}\left(r_{t+1}-\bar{r}\right) \text {, }
$$

where $\bar{r}=E\left(r_{t+1}\right)$ is the vector of expected returns of the $N+K$ assets. Note that $m_{t+1}^{*}$ is a portfolio return. Therefore, since it prices correctly (by construction), it is straightforward that this portfolio must lie on the (ex post) mean-variance frontier. Accordingly, the restriction for 
spanning is simply that the coefficients of $b(v)^{\prime}=\left(b^{K}(v)^{\prime}, b^{N}(v)^{\prime}\right)$ corresponding to the $N$ test assets are zero $\left(b^{N}(v)=0_{N}\right)$ for two distinct values of the expected SDF, i.e., $v_{1}=0$ and $v_{2}=1 /\left(1+r_{f}\right)$. The SDF restrictions for spanning are:

$b^{N}\left(v_{1}\right)=0_{N} \wedge E\left[m_{t+1}^{*}\left(v_{1}\right)\left(1+r_{t+1}\right)\right]-1_{N+K}=0_{N+K}$,

$b^{N}\left(v_{2}\right)=0_{N} \wedge E\left[m_{t+1}^{*}\left(v_{2}\right)\left(1+r_{t+1}\right)\right]-1_{N+K}=0_{N+K}$.

As in the regression-based test, testing only for one value of the expected SDF is an intersection test. GMM can be applied to estimate the asset pricing equations including the SDF constructed from the asset returns. The sample moments for this estimation are:

$\underbrace{h_{T}\left(b\left(v_{1}\right), b\left(v_{2}\right)\right)}_{2(N+K)+(N+K)}=\left[\begin{array}{c}\frac{1}{T} \sum_{t=1}^{T} r_{t}\left(v_{1}+b\left(v_{1}\right)^{\prime}\left(r_{t}-\bar{r}\right)\right)+v_{1}-1_{N+K} \\ \frac{1}{T} \sum_{t=1}^{T} r_{t}\left(v_{2}+b\left(v_{2}\right)^{\prime}\left(r_{t}-\bar{r}\right)\right)+v_{2}-1_{N+K} \\ \frac{1}{T} \sum_{t=1}^{T}\left(r_{t}-\bar{r}\right)\end{array}\right]$,

where the coefficients $b(v)$ are chosen to make the pricing errors $h_{T}(b(v))$ as small as possible (in fact zero, since the equations are exactly identified) by minimizing the GMM objective function:

$\min _{\{b(v)\}} h_{T}(b(v))^{\prime} W_{T} h_{T}(b(v))$.

The weighting matrix $W_{T}$ is set to the inverse of the covariance matrix of the sample moments to obtain an efficient GMM estimator. We apply the Newey-West method with Bartlett kernel and four lags, for a HAC robust sample covariance estimator. Finally, the null hypothesis (the coefficients for the test assets are zero, $b^{N}\left(v_{1}\right)=0_{N}$ and $\left.b^{N}\left(\bar{m}_{2}\right)=0_{N}\right)$ can be tested with a Wald test, $S D F_{H A C} \sim \chi_{2 N}^{2}$. 


\section{References}

Ang, A. and G. Bekaert. 2002 International Asset Allocation with Regime Shifts. Review of Financial Studies 15:1137-1187.

Bekaert, G. and M. Urias. 1996. Diversification, Integration and Emerging Closed-End Funds. Journal of Finance 51: 835-869.

Bekaert, G. and C. Harvey. 1995. Time-Varying World Market Integration. Journal of Finance 50: 403-444.

Bekaert, G., C.R. Harvey and A. Ng. 2005. Market Integration and Contagion. Journal of Business 78: 39-69.

Bond, S.A., G.A. Karolyi and A.B. Sanders. 2003. International Real Estate Returns: A Multifactor, Multicountry Approach. Real Estate Economics 31: 481-500.

Bris, A., W.N. Goetzmann and N. Zhu. 2007. Efficiency and the Bear: Short Sales and Markets Around the World. Journal of Finance 62: 1029-1080.

Campbell, J., K. Medeiros and L. Viceira. 2010a. Global Currency Hedging. Journal of Finance 65: 87-121.

Campbell, J., A. Sunderam and L. Viceira. 2010b. Inflation Bets or Deflation Hedges? The Changing Risks of Nominal Bonds. Working Paper.

Chen, H.-C., K.-Y. Ho, C. Lu and C.-H. Wu. 2005. Real Estate Investment Trusts. Journal of Portfolio Management - Special Issue: 46-54.

Chiang, K.C.H. and M.-L. Lee. 2007. Spanning Tests on Public and Private Real Estate. Journal of Portfolio Management 13: 7-15.

Dales, A. and R. Meese. 2001. Strategic Currency Hedging. Journal of Asset Management 2: 9-21.

De Jong, F. and F.A. de Roon. 2005. Time-Varying Market Integration and Expected Returns in Emerging Markets. Journal of Financial Economics 78: 583-613.

De Roon, F.A. and T.E. Nijman. 2001. Testing Mean-Variance Spanning: A Survey. Journal of Empirical Finance 8: 111-155. 
De Roon, F.A., T.E. Nijman and B.J.M. Werker. 2001. Testing for Mean-Variance Spanning with Short Sales Constraints and Transaction Costs: The Case of Emerging Markets. Journal of Finance 56: 721-742.

De Roon, F. A., T.E. Nijman and B.J.M. Werker. 2003. Currency Hedging for International Stock Portfolios: The Usefulness of Mean-Variance Analysis. Journal of Banking and Finance 27: 327-349.

Driessen, J. and L. Laeven. 2007. International Portfolio Diversification Benefits: CrossCountry Evidence from a Local Perspective. Journal of Banking and Finance 31: 16931712.

Eichholtz, P.M.A. 1996. Does International Diversification Work Better for Real Estate than for Stocks and Bonds?. Financial Analysts Journal 52: 56-62.

Eun, C.S. and J. Lee. 2010. Mean-Variance Convergence around the World. Journal of Banking and Finance 34: 856-870.

Eun, C.S. and B. Resnick. 1988. Exchange Rate Uncertainty, Forward Contracts, and International Portfolio Selection. Journal of Finance 43: 197-216.

Eun, C.S., S. Lai, F.A. de Roon and Z. Zhang. 2010. International Diversification with Factor Funds. Management Science 56: 1500-1518.

Glabadanidis, P. 2009. Measuring the Economic Significance of Mean-Variance Spanning. The Quarterly Review of Economics and Finance 49: 596-616.

Glen, J. and P. Jorion. 1993. Currency Hedging for International Portfolios. Journal of Finance 48: 1865-1886.

Goetzmann, W.N., L. Li and K.G. Rouwenhorst. 2005. Long-Term Global Market Correlations. Journal of Business 78: 1-38.

Gouriéroux, C., A. Holly and A. Montfort. 1982. Likelihood Ratio Test, Wald Test, and Kuhn-Tucker Test in Linear Models with Inequality Constraints on the Regression Parameters. Econometrica 50: 63-80.

Grubel, H.R. 1968. Internationally Diversified Portfolios: Welfare Gains and Capital Flows. American Economic Review 58: 1299-1314.

Hansen, L.P. and R. Jagannathan. 1991. Implications of Security Market Data for Models of Dynamic Economies. Journal of Political Economy 99: 225-262. 
He, H. and D.M. Modest. 1995. Market Frictions and Consumption-Based Asset Pricing. Journal of Political Economy 103: 94-117.

Huberman, G. and S. Kandel. 1987. Mean-Variance Spanning. Journal of Finance 42: 873888.

Jobson, J.D. and B. Korkie. 1989. A Performance Interpretation of Multivariate Tests of Asset Set Intersection, Spanning, and Mean-Variance Efficiency. Journal of Financial and Quantitative Analysis 24: 185-204.

Jorion, P. 1994. Mean/Variance Analysis of Currency Overlays. Financial Analysts Journal 50: 48-56.

Kan, R. and G. Zhou. 2008. Tests of Mean-Variance Spanning. Working Paper.

Kodde, D.A. and F.C. Palm. 1986. Wald Criteria for Jointly Testing Equality and Inequality Restrictions. Econometrica 54: 1243-1248.

Liu, C.H. and J. Mei. 1998. The Predictability of International Real Estate Markets, Exchange Rate Risks and Diversification Consequences. Real Estate Economics 26: 3-39.

Luttmer, E.G.J. 1996. Asset Pricing in Economies with Frictions. Econometrica 64: 14391467.

Longin, F. and B. Solnik. 1995. Is the correlation in international equity returns constant: 1960-1990?. Journal of International Money and Finance 14: 3-26.

Longin, F. and B. Solnik. 2001. Extreme Correlation on International Equity Markets. Journal of Finance 56: 649-676.

Palazzo, G. and S. Nobili. 2010. Explaining and Forecasting Bond Risk Premiums. Financial Analysts Journal 66: 67-82.

Perold, A. and E. Schulman. 1988. The Free Lunch in Currency Hedging: Implications for Investment Policy and Performance Standards. Financial Analysts Journal 44: 45-50.

Rubens, J.H., D.A. Louton and E.J. Yobaccio. 1998. Measuring the Significance of Diversification Gains. Journal of Real Estate Research 16: 73-86.

Sa-Aadu, J., J. Shilling and A. Tiwari. 2010. On the Portfolio Properties of Real Estate in Good Times and Bad Times. Real Estate Economics 38: 529-565.

Schroeder, M. 2000. Investment Opportunities in Central and Eastern European Equity Markets. ZEW Discussion Paper No. 00-42. 
Serrano, C. and M. Hoesli. 2009. Global Securitized Real Estate Benchmarks and Performance. Journal of Real Estate Portfolio Management 15: 1-19.

Solnik, B.H. 1974. Why Not Diversify Internationally Rather Than Domestically?. Financial Analysts Journal 30: 48-54.

Worzala, E. and C.F. Sirmans. 2003. Investing in International Real Estate Stocks: A Review of the Literature. Urban Studies 40: 1115-1149. 